\title{
Character Education in Quran: \\ Thematic Interpretation of QS Luqman: 12-19 and Its Relevance to Character Education by the National Ministry of Education
}

\author{
Deri Wanto ${ }^{1}$, Jalwis ${ }^{2}$ \\ ${ }^{1}$ Institut Agama Islam Negeri (IAIN) Curup, ${ }^{2}$ Institut Agama Islam Negeri (IAIN) Kerinci \\ 11deriwanto@iaincurup.ac.id, 2jalwisiain3@gmail.com
}

DOI: 10.29240 /alquds.v5i2.2778

Submitted: 2021-05-06 | Revised: 2021-08-20 | Accepted: 2021-11-02

\begin{abstract}
In Surah Luqman Verses 12-19 contained the formulation of educational values primary of character education. Research on the content of the verse is necessary and compelling to instill character values in children and at the same time berate children from environmental influences. This study uses a qualitative strain with library research. The purpose is to know the values of character education contained in the Surah Luqman verses 12-19 and to determine its relevance to the character education of the Ministry of National Education. Content analysis is a method used for textual and language. This research carried out the three points of education as a reference in educating children. The points are Tawhid, Islamic laws, and moral education. Other results through this research are several methods used in instilling character values; (a) Method by example or qudwah Hashanah, (b) Method of story, and (c) Method of advice..
\end{abstract}

Keyword: Relevance; Character building; Surah Luqman 12-19; Ministry of National Education

\section{Introduction}

The idea of character education in Indonesia is a necessity. It causes, Indonesia's education has not succeeded in constructing human resources which is relevant to the goals of national education. The holistic evidence is school only focused on intellectual intelligence with no moral and mental importance. On the other hand, teachers cannot be role models for students. Students teach to memorize courage, hard work, honesty, cleanliness, and not cheating, but only limited to test scores. So that, the Ministry of National Education try to strengthens the National character through eighteen characters education, Presidential Regulation Number: 87 of 2017. Furthermore, through the issuance 
of a Presidential Regulation on (Strengthening Character Education) schools are expected to create character education-based learning.

In-Law no. 20 of 2003 Article 3 states that, the function of national education is to develop capabilities and shape the character and civilization of a dignified nation in the context of educating the nation's life, aiming at developing the potential of students to become human beings who believe and fear God Almighty, have a noble character, are healthy, knowledgeable, capable, creative, independent, and become a democratic and responsible citizen. It can be understood, that the improvement of human resources not only in terms of science but also in character. An effort to form the character of a mature person required a continuous process and continues throughout life. This process begins early as the age of the child is the right time to instill character values.

Based on the phenomenon it can be concluded, character education can be an alternative way to overcome the problems of delinquency in children. The failure to cultivate character will form a problematic personality in the future. So in this paper, the author will reveal character education in the Qur'an (a study of the letter Luqman verses 12-19) and its relevance to the character education of the Ministry of National Education. This research is a study of the content of character education values in the letter Luqman verses 12-19 and to see its relevance to character education proposed by the Ministry of National Education. To achieve the research objectives, a qualitative research approach is used with the type of library research; the method of interpretation of the Qur'an used is maudhu' $i$ with a thematic form of verses. It's revealing a certain concept from verses of the Qur'an. In this study, the authors examine the concept of character education in QS. Luqman verses 12-19

\section{Result and Discussion}

Russell T. Williams mentions that character education is the process of formation of ethics which involves three aspects, knowledge (cognitive), feeling, and action. If three aspects integrate it will form the process of the formation of character. Lickona in his book educating for Character states that the character itself has three elements that have a strong relationship: (1) moral knowing, (2) moral feeling, and (3) moral behavior. ${ }_{-}{ }^{1}$ This is necessary so that the child can understand, feel and do it. This is necessary so that the child can understand, feel and do is at once the value-the value of virtue.

Moral knowing consists of six things: moral consciousness, knowing moral values, perspective-taking, moral reasoning, decision making, and selfknowledge. Six things are emotional aspects that should be able to be felt by a 
person; consciences, self-esteem, empathy, love the truth, self-control, and humility. Moral action is how to implement moral values in real life. The deeds of moral action are an outcome of the two-component character. To understand what drives someone in a good deed then should be seen three other aspects of the Character, competence, desire, and habit. ${ }^{2}$ The third moral above translated into several embodiments of attitudes and actions. Meanwhile, when viewing the character education events calendar then found 18 values in the educational development of the culture and morals of the nation. Starting in the school year of 2011, the entire level of education in Indonesia should insert the moral education is in the process of education; Religious, Honest, Tolerance, Discipline, Hard work, Creative, Independent, Curiosity, Democratic, The spirit of nationality, Calm, Appreciate, Friendly, Nationalism, Love to Read, Environment care, Social care, Responsibility. When seeing the concept of character education in the Qur'an, especially in Surah Luqman verses 12-19, it contains three aspects of Character education, namely aqeedah, Islamic law, and moral education. Aqeedah includes monotheism prohibitions do shirk. The education of sharia, including an order of worship which establishes the prayer, and the command of Amar ma'ruf nahi Munkar (do well). Moral education in the advice of Luqman to his son covers, grateful for the favors of Allah and do not deny, do good to parents, the prohibition applies arrogant, and the command to say and talk politely.

These Data show that so urgent character education in the implementation for everyday life. Character education in the Ministry of National education is very relevant to what contains in al-Quran surah Luqman verses 1219.

\section{Character building; a Definition Overview}

A character is a derivative form of Latin, kharassein, and kharax interpreted as tools for making. ${ }^{3}$ This word comes from the French word caractere began to widely used in the 14th century adapted into Indonesian into a "character". Another definition Hornby and Parnwell in Hidayatullah defines character as a mental/moral quality, moral strength, name, or reputation. ${ }^{5}$ Meanwhile, according to Zakiyah Darajat morals is a force that is following the standards of society that grows from the heart and not coercion from the outside accompanied by a sense of responsibility for the behavior of these actions. The action must

\footnotetext{
${ }^{2}$ Majid and Andayani, Pendidikan Karakter Perspektif Islam, 31.

${ }^{3}$ Elmubarok, Membumikan Pendidikan Nilai; Mengumpulkan Yang Terserak, Menyambung Yang Terputus, Dan Menyatukan Yang Tercerai, 102.

${ }^{4}$ Elmubarok, 103.

${ }^{5}$ Hidayatullah, Guru Sejati: Membangun Insan Berkarakter Kuat Dan Cerdas, 9.
} 
precede the public interest over private desire. ${ }^{6}$ Heraclitus a Greek philosopher, Lickona said "character is destiny"7 (a character is a goal). A character is a basis that an individual will aim at. If the character is good, then the goals achieved will be good too. This individual character will produce a community/group of individuals leading to the formation of the nation's character. Therefore, the development of national character can be done through individual character development first. In line with that Covey said that "you must do well, and to do well, you must first be good"8. This means that to be good is not only limited to intentions or planning but the most important of all is the implementation of actions that look real so that by acting well, it is necessary to have planning and intentions in the heart. Thus, character education is an effort to influence all the thoughts and inner nature of students to shape their character, character, and personality. ${ }^{9}$ Meanwhile Santrock ${ }^{10}$ said that character education is a direct approach to moral education, namely teaching students basic moral knowledge as a preventive effort to prevent immoral actions and endanger themselves and others. Furthermore, to instill character values in schools, schools must have clear moral rules (a kind of code of ethics) that are socialized, clearly communicated to students that every violation of school rules has sanctions imposed. Therefore, it can be concluded that character education is the embodiment of a person that can be seen and observed by others through the process of socialization and communication between individuals created from the nature and habituation of each individual within the scope of events experienced by the individual both in the social, family, and school environment. The result of habituation will create a value that leads to the formation of the character of each individual that distinguishes him from other individuals.

\section{The Urgency of Character Education}

Based on the facts, in the last twenty years, the behavior of many community members has deviated and is no longer following noble values. As an example; individualistic attitude Authoritarian using all means to achieve goals, including by violating the law such as corruption and blackmailing citizens; a culture of conflict and mutual suspicion; criticizing and dropping each other, fighting each other, the culture of masses, and the culture of shamelessness. Especially in education, deviant behavior among youth is increasing. For example, drugs, promiscuity, brawl, robbery, and thuggery. Dishonesty during the exam is carried out in congregation by students, teachers, and related parties. Likewise, the misappropriation of School Operational Assistance funds at the unit level.

\footnotetext{
'Jamil and Wanto, Psikologi Agama Dan Kesehatan Mental, 182.

${ }^{7}$ Lickona, Educating For Character: How Our School Can Teach Respect and Responsibility, 4.

${ }^{8}$ Covey, The 8th Habit: From Effectiveness to Greatness, 39.

PPoerwadarminta, Kamus Umum Babasa Indonesia, 1149.

${ }^{10}$ Santrock, Psikologi Pendidikan, 97.
} 
This is in line with Thomas Lickona's prediction. That a nation is heading towards the brink of destruction if it has the ten signs of the times that are; the culture of dishonesty, increased violence among students, the development of a fanatical attitude towards the group; deteriorating use of language; less respect for parents and teachers; the blurring of good and bad morals; increased self-destructive behaviors such as the use of drugs, alcohol and casual sex; the low sense of responsibility as individuals and as citizens; decreased work ethic; the existence of mutual suspicion and lack of apathy. ${ }^{11}$ Lickona's expression can be found in Indonesian society lately. This condition indicates that character education in schools which have been developed through religious education and civic education, has failed to form students with character because it has not touched the level of introducing norms or values, and has not been at the level of internalization and real action in everyday life. . In other words, both materials, methods, the curriculum needs to be reviewed in-depth to be able to produce quality students both in terms of intellect and morality. The phenomenon indicates that strengthening character education is necessary as a preventive effort to save the younger generation, the successor to the nation's leadership from moral damage and multidimensional crises

\section{Character values in QS Luqman: 12-19}

Luqman's can be a guide in educating children with character. Alwasilah ${ }^{12}$ explained that educating people can be done in two ways, namely using faith and righteous deeds. Faith refers to the cognitive (reasonable) and affective (emotional and feeling) aspects and charity is a psychomotor aspect. While the task of educators, in this case, is to perfect character and instill a balance between science and charity or theory and practice. The character values contained in the letter Luqman verses 12-19 are;

\section{The Value of Gratitude Character Education in verses 12;}

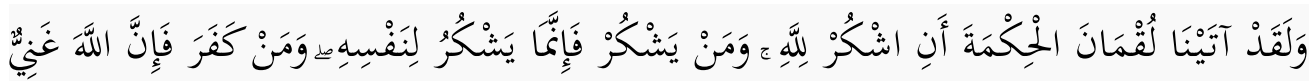

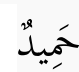

And we had certainly given Luqman wisdom (and said) "be grateful to Allah." And whoever is grateful; for (the benefit of) bimself. And whoever denies (His favor) then indeed, Allah is free of need and Praiseworthy

${ }^{11}$ Lickona, Educating For Character: How Our School Can Teach Respect and Responsibility, 12

${ }^{12}$ Alwasilah and Chaedar, Filsafat Bahasa Dan Pendidikan, 35. 
The Word of The verse above, explained by Quraish Shihab by referring to the opinion of al-Biqa'i, the word wisdom means knowing the most important of all things, both knowledge and deeds. It is the amaliah and scientific knowledge. By Imam al-Ghazali, he said wisdom in the sense of knowledge of the most important thing and the most sublime being, Allah Subhanahu Wata'ala. According to al-Ghazali Allah is the true judge, because He has the eternal knowledge. His essence and attributes are not reflected in the mind, nor are they subject to change. ${ }^{14}$ Only He knows the noblest form because only He knows His essence, essence, nature, and actions. This means that if Allah bestows wisdom on someone, then the one who is awarded (the judge) gets a lot of virtue. Choosing the best and appropriate is the embodiment of wisdom. ${ }^{15}$

The word فَشْكُ among other things, praise for goodness, and the fullness of something. A grateful man begins with an awareness that grows from the bottom of his heart, how great His favors and gifts are, accompanied by submission, obedience, and admiration so that it gives birth to a sense of love and an urge to praise while internalizing what He wants from the bestowal. Thus, grace can function at once. His Word: is wisdom itself that is bestowed. That wisdom is gratitude because, with gratitude as mentioned above, one knows Allah and His grace. By knowing Allah we will be amazed and obedient to Him, and by knowing Allah and knowing the function of His grace, no one will have true knowledge, then on the impulse of gratitude, he will do deeds according to his knowledge, so that the deeds that are born are a proper charity.

Therefore, it is stated by Quraish Shihab that there are three elements of action so that what he does can be commendable. First, the deed is beautiful or good. Second, do it consciously. Third, it is not based on compulsion or coercion. ${ }^{16}$ In this regard, Quraish Shihab also emphasized that gratitude includes three sides. First is gratitude with the heart, inner satisfaction for the gift. Second is gratitude with the tongue which is acknowledging grace and praising to the giver. Third, gratitude by deeds, namely by utilizing the gifts obtained following the purpose of bestowing them accordance to bestow them. More than that, the Qur'an also instructs Muslims to be grateful after mentioning some of His blessings (S. Al-Baqarah: 152). ${ }^{17}$ That's why we are taught by Allah to say "Alhamdulillab", which means "all praise is for Allah". However, this does not mean that we are forbidden to be grateful to those who mediate the presence of God's blessings. For example, the Qur'an expressly commands us to be grateful

\footnotetext{
${ }^{13}$ Shihab, Tafsir Al Misbab; Pesan, Kesan Dan Keserasian Al Quran, 278.

${ }^{14}$ Shihab, 292.

${ }^{15} \mathrm{Al}-{ }^{-U}$ Umar, Al-Hikmah, 14.

${ }^{16}$ Shihab, Tafsir Al Misbab; Pesan, Kesan Dan Keserasian Al Quran, 295.

${ }^{17}$ Shihab, 234.
} 
to Allah and to be grateful for both parents who mediate our presence on the stage of this world (Surah Luqman: 14). Thus, teaching students about how to be grateful to Allah SWT is still very relevant to the world of education today. This also shows the relevance of the education of the Ministry of National Education with the Qur'an as stated in the letter Luqman verse 12.

\section{The value of Wise Character Education in verses 13;}

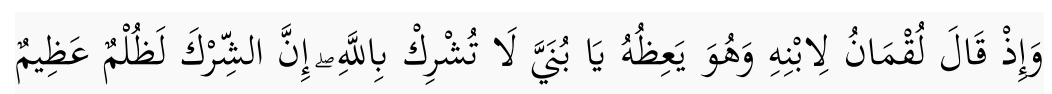

and (mention, O Mubammad) when Luqman said to bis son while he was instructing bim" $O$ my son, do not associate (anything) with Allah. Indeed association (anything with bim is great in justice.

This verse emphasizes the importance of faith as the main foundation of every human being. So that Muslims are obliged to believe with all their heart in the existence of Allah SWT. Unbelieving in associating partners with Allah is called shirk, which associates partners with Allah with His creatures, such as statues, large trees, stones, and others. This action is said to be a great injustice because it means putting something out of place. As Muslims, we know that monotheism is the highest principle in Islam. So that the act of denying monotheism by associating partners with Allah is a major sin that cannot be tolerated, except with true repentance (taubat nasuba). One of the normative foundations of character education derives from the holy book of religion. In the context of Islam, the Qur'an and Hadith are the main guidelines and references in behavior. The prohibition of associating partners with Allah in Islam obeyed and implemented because it is a command and religious teaching as a form of acknowledgment of the power of Allah SWT. The normative basis is needed considering that values and norms are not neutral but have a partiality to a higher source. Thus the importance of faith character education is based on religious values because it is the truth of Allah's revelation or to borrow the term Jamal Ma'mun Asmani (2012: 64) which is also called moral conservation. Associating partners with Allah is called shirk, while those who associate partners with Allah are called polytheists. Luqman's advice in the above verse illustrates internalizing Allah's commands and following the way of life of the believer.

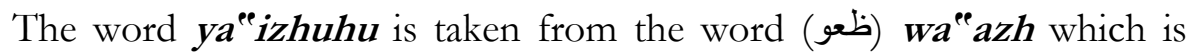
advice related to various virtues by touching the heart. Some interpret it with words that contain warnings and threats. The mention of this word shows how he conveyed those words, namely not loudly or yelling, but full of tenderness and affection as understood from his intimate call to children. The word ابنَئinaya is a patron that describes smallness. The origin is (ينب) ibniy, from the word (نبا) ibn i.e. son. The picking is a sign of love so as not to abolish Allah because it is a 
major $\sin ^{18}$ The meaning of inna al-syirka la zhulmun al-azhim associating partners with Allah is a great injustice. From this, it is understood that the verse above gives a clue; education should be based on love for students. And Luqman's statement above is reinforced by two stresses, the first begins with the prohibition of committing shirk, and the second reason by using the letter inna which means real, and the letter la which means really. ${ }^{19}$ His shows that several aspects are very urgent for parents to pay attention to, namely worship education, moral education, and Islamic faith education. Every development is always based on and based on the right aqeedah, ${ }^{20}$ Likewise, akhlakul karimah (goog attitude), or the character which teaches children beautiful sentences will affect the child's psychology. This foundation gives the meaning that the family environment factor is the first rank that will provide the basic color for children's religious values. Thus, every parent should give their child a strong aqeedah as early as possible to avoid shirking understanding and behavior. It shows the relevance of the education of the Ministry of National Education with the Qur'an as stated in the letter Luqman verse 13

\section{The Character Value on Verse 14}

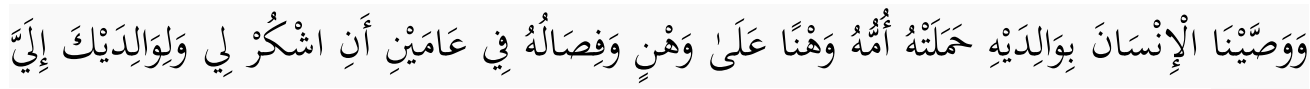
الْمَصِير

"'And We have enjoined upon man [care] for his parents. His mother carried him, [increasing ber] in weakness upon weakness, and his weaning is in two years. Be grateful to $\mathrm{Me}$ and to your parents; to Me is the [final] destination."

In al-Misbah, Quraish Shihab explains the word wahnan means weakness or frailty. This means the lack of ability to carry the burden of pregnancy, breastfeeding, and child care. Patron's word used in this verse implies how weak a mother is to the point that he described weakness as his own, which is all that is associated with weakness has been fused and carried by the mother. His word is wa fisholuhu fi'amain and he will finish it in two years. Suggests how breastfeeding a child is very important by the birth mother. The goal is not just to maintain the survival of children in excellent physical and psychological conditions. The word fi/implies that the period was not so. On the other hand, it is emphasized that the period of two years is for anyone who wants to perfect his breastfeeding. Then this verse explains the purpose of "doing good" which $\mathrm{He}$ commands in verse 14, namely that humans should always be grateful for His blessings and be grateful to their parents for raising them. Furthermore, Al-

\footnotetext{
${ }^{18}$ Mubarak bin Muhammad al-Maili, Risalah Al-Syirik Wa Madhabiribi, 10. ${ }^{19}$ Quthb, Tafsir Fi Zhilalil-Qur'an: Di Bawah Naungan Al-Qur'an, 173.

${ }^{20}$ Halim, Anak Soleb Dambaan Keluarga, 92.
} 
Maraghy explained that the way children are devoted to their parents is to obey and fulfill their rights. ${ }^{21}$ Meanwhile, according to Mahmud al-Alusiy al-Baghdadi, the way to be filial to both parents is to pay attention and take care of them. ${ }^{22}$ So in verse 14 , it contains the value of character education, namely the character of pious deeds. Therefore, teaching children to always be devoted to their parents is a must that cannot be ignored.

\section{The Character Value on Verse 15}

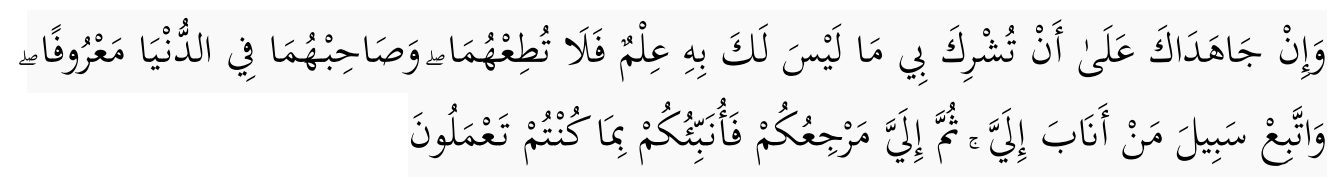

'But if they endeavor to make you associate with Me that of which you bave no knowledge,' do not obey them but accompany them in [this] world with appropriate kindness and follow the way of those who turn back to Me [in repentance]. Then to Me will be your return, and I will inform you about what you used to do."

The word (جَاهَدَاكَ) jahadaka in the above verse is taken from the word (دج) juhd which is able. If the effort is prohibited, which in this case can be in the form of a threat, and then of course even more so it can be just a call or a warning. What is meant by مَالَيْنَلَكَبَّه ma laisalakabihi'ilm you do not know about it, it means there is no knowledge about the possibility of it happening. Lack of knowledge means the absence of known objects. This means that there is no form of anything that can be associated with Allah SWT. the evidence of the oneness of God and no partner for Him is too much so that this passage is an affirmation of the prohibition of following anyone-even both parents and even by forcing the child to associate God. The word (مَعْرُوفًا) ma'ruufan includes everything that is judged by good society, as long as it does not contradict Islamic beliefs. In this context, it is narrated that Asma is the daughter of Abu Bakr. He was once visited by his mother who was still a polytheist at the time. Asma is "asked the Prophet as what she should behave, so the Prophet saw. Order her to maintain a good relationship, accept and give him gifts, and visit and welcome his visit. In the father's advice to his son, the Qur'an describes the relationship between both parents and their children in detailed and thorough grammar. God describes this relationship in a picture that signifies love and tenderness. However, the bond of faith must be preceded by a strong blood relationship. ${ }^{23}$

${ }^{21}$ Al-Maraghiy, Tafsir Al-Maraghiy, 82.

${ }^{22}$ Al-Baghdadiy, Rub Al-Ma'aniy Tafsir Al-Qur'an Al-'Adzim Wa Al-Sab' Al-Matsaniy, 129.

${ }^{23}$ Quthb, Tafsir Fi Zhilalil-Qur'an: Di Bawah Naungan Al-Qur'an, 174. 
So it becomes obligatory for parents to first do something that reflects the teachings of religion to their children. If the parents tell you to do shirk, never be obeyed, even if you have to keep dealing with the good in the world. This means that although the parents are the ones who serve their children, still the parents are ordinary human beings with shortcomings, so it does not rule out the possibility of the parents do not understand or believe in their children. However, with God's policy, the bond of monotheism remains at number one, meaning that it is God who must be given priority and not the blood bond between children and parents when it comes to the orders of parents who want polytheism. Based on the above verse, it can be understood that obedience to God is obligatory, as well as obedience to both parents, only according to al-Maraghi obedience to God is absolute and obedience to both parents is highly recommended. If both parents order shirk, then it is not obligatory to obey.

\section{The Character Value on Verse 16}

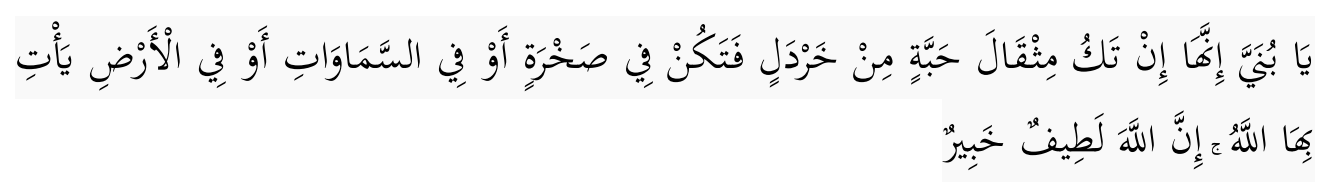

"[And Luqmān said], "O my son, indeed if it [i.e., a wrong] should be the weight of a mustard seed and should be within a rock or [anywhere] in the heavens or in the earth, Allah will bring it forth. Indeed, Allah is Subtle and Aware"

This verse is a continuation of Luqman's will to his son. What is described is the depth of Allah's knowledge, which is also required by the closing of the last verse with His statement "So I tell you what you have done". When interpreting the word (khardal), Quraish Shihab cites the explanation of Al-Muntakab's interpretation which illustrates the seeds. There it is stated, one kilogram of khardal / mustard seeds consists of 913,000 grains. Thus, the weight of 1 (one) mustard grain is only about one per thousand grams, or approximately 1 (one) $\mathrm{mg}$, and is the lightest grain known to mankind until now. Therefore, this seed is often used by the Qur'an to designate something very small and subtle. Lathief is taken from the root word lathafa whose letters consist of (lam), (tha) and (fa). This word contains the meaning of gentle, subtle, or small from this meaning wideness and thoroughness. According to Imam al-Ghazali, those who have the right to bear this trait are those who know the details of the benefit and the intricacies of its secrets, small and subtle, then take away to convey it to those who are entitled to be gentle, not violent. If you meet meekness in treatment and details in knowledge, then the culprit is naturally bearing the name Lathif. This of course cannot be done except by Allah, the All-Knowing.

One narration states, as al-Bagdadi this verse is the end of Luqman's will, then died. The majority of Mufassirs believe that what is meant by "any act" in 
the paragraph above is an act of $\sin .^{24}$ whatever its form, Allah will know it and will reveal it on the Day of Resurrection. Nothing escapes Him. Therefore, parents must teach the concept of reward and sin that all their actions will be accounted for before Allah SWT. No matter how small a child does, his ability must be appreciated because it will encourage him to produce something useful for society, and acknowledge and appreciate the success of others. In verse 16 of Surah Luqman, it contains the value of character education, namely being friendly. A friendly attitude is shown by pleasant attitudes and behavior towards children, both speech and manners.

\section{The Character Value on Verse 17}

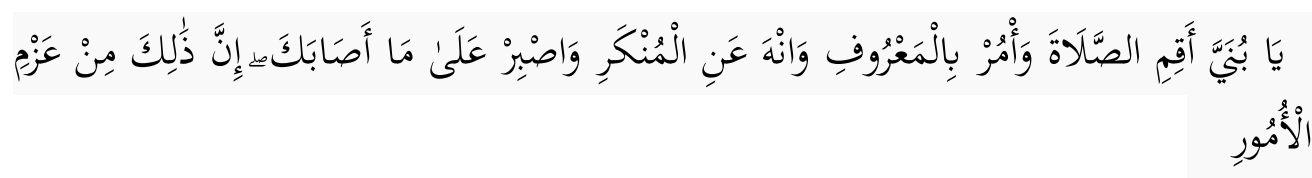

O my son, establish prayer, enjoin what is right, forbid what is wrong, and be patient over what befalls you. Indeed, [all] that is of the matters [requiring] resolve

There are three aspects of Islamic education in the above verse, namely prayer education, Amar ma'ruf nahi Munkar education, and patient education. As for the case with prayer, prayer is a very important task; the command of prayer is said by Allah SW'T, several times in the Qur'an, which alone is enough to show how important prayer is. In addition, prayer is also one of the messages that are always bequeathed by the Prophets, the guardians, the pious, and the wise parents. One of Luqman's very wise messages to his son was to establish prayer, as well as the prayer of Ibrahim as.

In the Interpretation/tafsir of al-Jilaniy, Shaykh 'Abdul Qādir Al-Jailānī explained that the purpose of prayer is to keep away from heinous deeds that are composed of lust and anger and to keep away from evils that are composed based on human nature and physical preoccupation.. ${ }^{25}$ While Ibn 'Ajībah said that prayer will be avoided from heinous deeds, bad deeds such as adultery, drunkenness, etc., keep away from evil means, what he denies from the Shari'ah and reason, there is no doubt that prayer if done correctly based on outward and inner, then it will be farthest from heinous and evil deeds ${ }^{26}$ Luqman then continued with the burden of aqeedah, namely the command of Amar makruf nahi Munkar, and to be patient with all the consequences. Because there is no deed for taqarrub to Allah SWT unless the reward from patience, as explained by al-Imam al-

\footnotetext{
${ }^{24}$ Al-'Adawy, Fiqh Tarbiyah Abna' Wa Thaifah Min Nasha'ih Al-Atbibba, 195.

${ }^{25}$ Al-Jīlāni, Tafsir Al-Jìlāni, 306.

26‘Ajībah, Al-Babr Al-Madid Fi Tafsir Al-Qur'anAl-Majid, 306.
} 
Maqdisy. ${ }^{27} \mathrm{Al}-\mathrm{Maraghi}$ also explains that what is meant by al-makruf is $\mathbf{m a}$ istahsanu al-syar'wa al-aql (something that is considered good by reason and religion). While Munkar is dhidduhu (the opposite of makruf). ${ }^{28}$ In the meantime, Muhammad Abduh said that fa al-amr bi al-ma'ruf wa al nahyu 'an al-mungkar huffadz al-jama'ah wa siyaj al wahdah, also emphasizes the existence of education that is dialogical between parents and their children to choose between good and bad. ${ }^{29}$ The process of dialogue in education is one of the forms in which education can provide space for thinking to learners. This is one of the values of education that delivers and dialogues learners towards the reality of answering actual problems and needs.

In addition, parents become role models in front of their children. By setting a good example, it means doing makruf in the form of establishing moral, spiritual, and social ethos for the child, so that a child will grow into an honest person, with noble morals, brave to face challenges.

Therefore, teaching these three materials to children is very important so that children get used to do Amar ma'ruf nahi mungkar as the goal of prayer and have the nature of patience in facing all obstacles and obstacles.

\section{The Character Value on Verse 18}

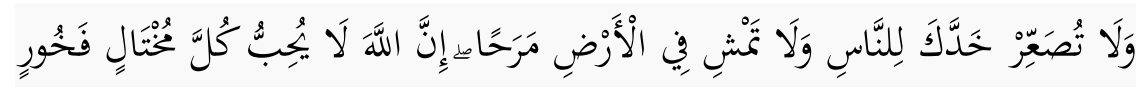

And do not turn your cheek [in contempt] toward people and do not walk through the earth exultantly. Indeed, Allah does not like everyone self-deluded and boastful.

Arrogance and arrogance are very dangerous for humans. That's why there are many verses of the Qur'an and Hadith that warn people to stay away from being arrogant and arrogant. Even the Holy Prophet said that a person who has pride in his heart - even as small as a mustard seed or even an atom - will not be able to enter Paradise. Quraish Shihab, in his commentary, explained that this verse was Luqman Al-Hakim's advice to his son to have good morals and manners when interacting with fellow human beings.

The word mukhtālan is taken from the same root as khayā or khayal. Therefore this word originally meant a person whose behavior was directed by imagination, not reality that exists in him. Usually, this kind of person walks arrogantly and feels he has an advantage over others. As a result, arrogance is evident in his daily life. While the word fakhüran means to boast like a horse whose way of walking suggests arrogance? These two words, namely mukhtālan and fakhüran, contain the meaning of arrogance; the first word means arrogance

\footnotetext{
${ }^{27}$ Ahmad, Mukbtashar, 335-36.

${ }^{28}$ Al-Maraghiy, Tafsir Al-Maraghiy, 21.

${ }^{29 ‘}$ Abduh, Tafsir Al-Manar, 26.
} 
that is seen in behavior, while the second is arrogance that is heard from speech. On the other hand, it should be noted that the combination of the two words mukhtālan and fakhūran - in the verse above if one of the two qualities is carried by humans, then it has invited His wrath. Based on the explanation above, it can be seen that QS. Luqman [31] verse 18 commands humans not to act arrogantly on the face of the earth; no matter how small it is, whether in attitudes, feelings, words, or deeds, because it can cause the wrath of Allah SWT. This verse contains the value of humble character education. Therefore, teaching these materials to children is very important so that children are accustomed to being grateful and always have a humble nature to others.

\section{The Character Value on Verse 19}

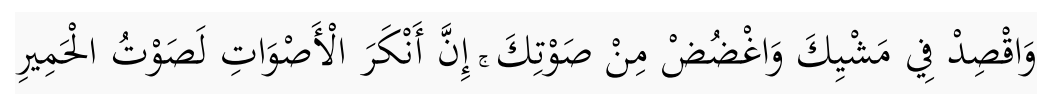

"And be moderate in your pace and lower your voice; indeed, the most disagreeable of sounds is the voice of donkeys."

According to al-Mawardi, this verse has five meanings; First, it means to humble oneself. Second, when walking looks at the road. Third, hasten in walking. Fourth, do not rush in walking. Fifth, do not be arrogant in walking. ${ }^{30}$ This verse contains the value of self-control character education. Self-control in question is restraint when walking, not in a hurry, looking at the road (down). Likewise, the voice must be softened when speaking. This means that Allah encourages His servants to always keep his tongue with good and useful words.

In the Qur'an, there are at least 6 terms from words that serve as a guide for a Muslim in good communication. Among others: (1) Qaulan S'adida (Surat anNisa: 9); (2) Qaulan Bali gha (QS. An-Nisa': 63); (3) Qaulan Ma'r' ufa (QS. Al-Baqarah: 235; QS. An-Nisa': 5 \& 8; QS. Al-Ahzab: 32); (4) Qaulan Karima (QS. Al-Isra': 23); (5) Qaulan Layina (QS. Thaha: 44); (6) Qaulan Maisu'ra (QS. Al-Isra': 28)(Principles of Islamic Communication). These six types of words lead to the principle of communication in Islam which is contained in the verse: لُو اللِنَّاسِحُسنْناً "And speak to all mankind in a good way (husna)" (Surah Al-Baqarah: 83) Parents should teach children with good words, sympathetic sentences, not loud or even yelling. Likewise, in the learning process carried out by educators, it should be with noble words as mentioned above. Because good and interesting words can give appreciation to children or students, from this it will also give birth to a good attitude, so students can digest what the teacher means and quickly understand it.

${ }^{30}$ Al-Tabãtabãi, Al-Mîããn Fi Tafsîr Al-Qur'an, 224. 


\section{The Relevance of the Value of Character Education in QS Luqman: 12-19 with the Value of Character Education of the Ministry of National Education}

The Curriculum Center of the Ministry of National Education formulates eighteen values that need to be developed through character education: ${ }^{31}$

\section{Religious}

The religious meaning is obedience in religion, namely surrendering to religious rules sincerely, daring to sacrifice body and mind, thoughts, and energy for the sake of religion. This attitude can produce a pious generation with noble character and obedience to religious rules.

\section{Honest}

Honesty is an effort to be trusted by others in words, actions and work is a noble character that must be applied by students in the learning process.

\section{Tolerance}

Tolerance is an act of respecting the behavior of others who have different attitudes. The attitude of tolerance between religious communities in social life is emphasized by Pancasila and the 1945 Constitution.

\section{Discipline}

An efforts to order and comply with regulations that can be applied in schools.

\section{Hard work}

The meaning of hard work is to do something seriously and work hard, the relevance of this value is the encouragement to work hard in the learning process which aims to get a good understanding so that the target of educational achievement can be maximized.

\section{Creative}

An effort to produce new works; this attitude is relevant to be applied by education in Indonesia which applies the attitude and creative thinking of a teacher when delivering lessons at school to his students so that they are not bored and boring. In this case, it takes patience from the teacher, so that students can get what the teacher hopes, can be creative.

\footnotetext{
${ }^{31}$ Pusat Kurikulum Departemen Nasional, Pusat Kurikulum Departemen Pendidikan Nasional, 14-16.
} 


\section{Independence}

The meaning of independence is an attitude that does not depend on others, the relevance of its goals is the same as education in Indonesia where every student must have an attitude of independence that is always trained in school and will be applied in their future lives.

\section{Democratic}

Democratic means not authoritarian and always involves other people in making a decision. This meaning is relevant to the application of education in Indonesia, where every teacher should always involve students in the learning process. Actively communicate to create a comfortable atmosphere in the learning process, not stressful and authoritarian.

\section{Curiosity}

Curiosity is the desire to always know something new. This is relevant to the purpose of education in Indonesia, namely to foster the curiosity and curiosity of students about science and material when the teaching and learning process takes place.

\section{Spirit of nationality}

A way of thinking, acting and having insight that the interests of the nation and state before the interests of themselves and their groups.

\section{Love the Motherland}

Love for the homeland is an effort to love culture and a sense of nationalism; these values have close relevance to the suggestion of love for the homeland which is realized by efforts to advance the nation's education. Loving the homeland can be realized through efforts to make Indonesia a gemah ripah Loh jinawi.

\section{Appreciate achievements}

It means respect and respect for the achievements of others. This value is relevant to the application of education in Indonesia because this attitude aims to strengthen brotherhood among fellow students.

\section{Friendly/Communicative}

Friendship is the attitude of being social and looking for friends. The relevance of the value of friendship has the same goal in the association of students with their friends, this is considered important because the aim is to add friends and 
friends so that social life is more comfortable, help each other, work together in dealing with life's problems.

\section{Peace-loving}

Peace-loving is an effort to make the community environment safe. The relevance of this attitude to education in Indonesia is that the goal of peace is a top priority for law enforcement in a country. If the country is peaceful and safe then all the people will feel happiness, without worrying about crime and criminalist.

\section{Love to read}

The desire to study and read books, articles, scientific works, and other sources of knowledge. This is very relevant to be practiced in Indonesia because one of the goals of education in Indonesia is to increase children's interest in reading. So that, his knowledge skyrockets the mindset becomes wiser.

\section{Environmental care}

Caring for the environment is an attitude of caring for environmental conditions, this attitude aims to make a person more sensitive to environmental conditions, in the village, or at school. A student is expected to be a person who is sensitive to the cleanliness, safety, and welfare of his environment. So that he also becomes part of the improvement in the natural surroundings.

\section{Social care}

The meaning of this attitude is to care about the social conditions of the community, this attitude aims to make a person more sensitive to the conditions of society, where this shows relevance to the conditions of society in Indonesia which aims to create a society that cares for each other or in other languages is called friendly.

\section{Responsibility}

The meaning of this value is the ability to carry out a business with full trust. This value objective is relevant to be applied in Indonesia, where the aim is to carry out the duties and obligations that must be carried out on oneself, society, environment, state, and religion as well as possible without any coercion and full of awareness

Based on the explanation above, it can be concluded that the values of character education as mentioned in the Ministry of National Education 18 characters above are very relevant to Luqman's letter, verses 12-19, and to today's 
education. Like the character of pious charity, including the hard work part, in terms of hard work, it must begin with sincere intentions, because work that starts with good intentions will give good results. Sincere intentions alone are not enough but internalization must always present Allah SWT in the form of piety (religious). that is to do all the commands and keep away all the prohibitions. The Intention because he aims to get the pleasure of Allah SWT. Good intentions will make life nobler. Among the good goals in working is solely worshiping Allah SWT from here will bring up an attitude of humility and not arrogance? then be grateful for any work whatever is obtained, because work is one of the blessings given by Allah SWT to His servants as mentioned in the Surah Ibrahim verse 7. "And remember, when your Lord declares, if you are grateful I will surely add it and if you disbelieve, then know that My punishment is very painful."

Al-Maragi makes an analogy of gratitude that "if the limbs are trained continuously to work and act, it can be ascertained that they will become stronger and healthier. But if he is dismissed, he will weaken and his energy will decrease as well as gratitude, if he continues to be grateful for it, he will feel greater and more things. But if you stop being ungrateful then it will decrease. A charity must be done seriously because sincere actions will produce maximum value even though later encountering obstacles and difficulties it is recommended not to give up easily because Allah SWT will provide a way for His servants who are willing to be patient in this case also includes the part of self-control. . In addition to obeying (respect) to superiors, they must also obey the rules that have been made and agreed upon, not only comply with the agreed rules but also be able to provide creations as a form of creativity, ideas, concepts or new ways. And no less important is a sense of responsibility for everything that happens as a result of the work done. This can be seen in the form of the following table. 


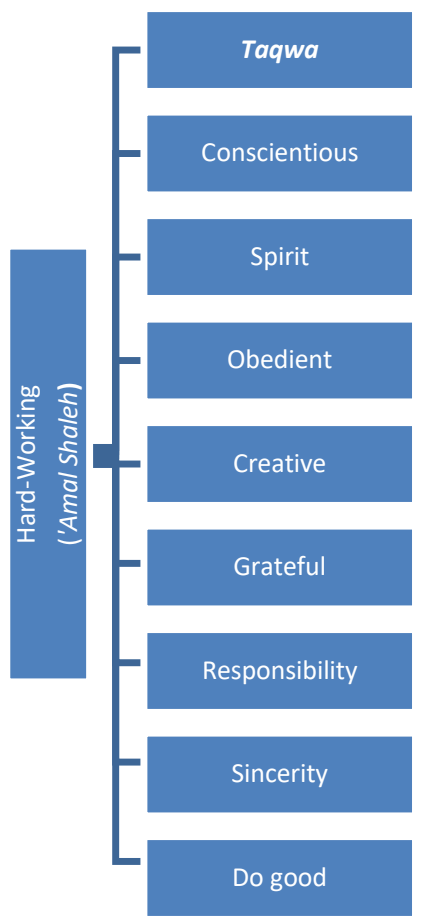

Based on this table, it can be seen that the characters in the Ministry of National Education and the characters in the letter Luqman 12-19 are interrelated which shows the relevance between the two. The things mentioned above need to be taught to students, these qualities include being grateful, wise, doing good deeds, respecting parents, teachers, being friendly to everyone regardless of social status and differences, being humble and not arrogant, and an attitude of selfcontrol. It is important that these attitudes are owned by students and are indispensable in the affective domain, and it is also necessary to use the habituation method. Because character is not formed instantly but must be nurtured and trained seriously, continuously, and professionally, in order to achieve a perfect human (insan Kamil).

\section{Conclusion}

Al-Quran contains the values of character education. These values are contained in various stories and wisdom scattered in the Qur'an. These educational values have close relevance to education and the learning process in Indonesia, both formal and non-formal institutions as stated in the 18 characters of the Ministry of National Education. Therefore, these values are very relevant to be applied and applied in schools, these values are not only found in Luqman's letter but are also found in other letters and verses in the Qur'An, among others; religious values (QS. an-Naml: 44), the value of honesty (QS. an-Naml: 27), the value of tolerance (QS. an-Naml: 18), the value of discipline (QS. an-Naml: 17), the value of hard work ( QS. an-Naml: 7), creative values (QS. an-Naml: 30), the 
value of independence (QS. an-Naml: 33), democratic values (QS. an-Naml: 32), the value of curiosity ( QS. an-Naml: 28), the value of national spirit and love for the homeland (QS. an-Naml: 33), the value of appreciating achievement (QS. anNaml: 4). It is hoped that other writers will dig deeper into the character values of the verses that the author mentions above

\section{Bibliography}

'Abduh, al-Imam al-Sayikh Muhammad. Tafsir Al-Manar. Mesir: ttt, n.d.

'Ajïbah, Ibn. Al-Babr Al-Madid Fi Tafsir Al-Qur'anAl-Majid. Kairo: ttt, 1999.

Ahmad, Al-Imam Asy-Syaikh. Mukhtashar. ttt: ttt, n.d.

Al-'Adawy, Abu Abdullah Musthafa ibn. Fiqh Tarbiyah Abna' Wa Thaifah Min Nasha'ih Al-Athibba. Jakarta: Press Qisthi, 2009.

Al- 'Umar, Nashir bin Sulaimân. Al-Hikmah. Riyâdh: Dar al-Wathan, 1412.

Al-Baghdadiy, Mahmud al-Alusiy. Ruh Al-Ma'aniy Tafsir Al-Qur'an Al-'Adzim Wa Al-Sab' Al-Matsaniy. Edited by Jil.12. Beirut: Dar al-Fikr, n.d.

Al-Jīlāni, 'Abd Qādir. Tafsir Al-Jìlāni. Kuwait-Bakistan: Maktabah Ma’rufiyah, 2010.

Al-Maraghiy, Ahmad Mushthafa. Tafsir Al-Maraghiy. ttt, n.d.

Al-Tabãtabãi, Muhammad Husein. Al-Mǐrãn Fi Tafsîr Al-Qur'an. Libanon: Muassasat al-'Ãlamîli al-Matba’ah, 1991.

Alwasilah, and A. Chaedar. Filsafat Babasa Dan Pendidikan. Bandung: Remaja Rosdakarya, 2012.

Covey, Stephen R. The 8th Habit: From Effectiveness to Greatness. New York: Free Press a Division of Simon and Schuster Inc, 2004.

Elmubarok, Zaim. Membumikan Pendidikan Nilai; Mengumpulkan Yang Terserak, Menyambung Yang Terputus, Dan Menyatukan Yang Tercerai. Bandung: Alfabeta, 2009.

Halim, M. Nipan Abdul. Anak Soleh Dambaan Keluarga. Yogyakarta: Mitra Pustaka, 2001.

Hidayatullah, M. Furqon. Guru Sejati: Membangun Insan Berkarakter Kuat Dan Cerdas. Surakarta: Yuma Pustaka, 2010.

Jamil, Jalwis, and Deri Wanto. Psikologi Agama Dan Kesehatan Mental. Yogyakarta: Samudera Biru, 2020. 
774 | AL QUDS : Jurnal Studi Alquran dan Hadis vol. 5, no 2, 2021

Lickona, Thomas. Educating For Character: How Our School Can Teach Respect and Responsibility. New York: Bantam Books, 1991.

Majid, Abdul, and Dian Andayani. Pendidikan Karakter Perspektif Islam. Bandung: Remaja Rosdakarya, 2011.

Mubarak bin Muhammad al-Maili. Risalah Al-Syirik Wa Madhahiribi. Gontor: alTauhid, n.d.

Poerwadarminta, W.J.S. Kamus Umum Bahasa Indonesia. Jakarta: Balai Pustaka, 2003.

Pusat Kurikulum Departemen Nasional. Pusat Kurikulum Departemen Pendidikan Nasional, Pub. L. No. nomor 03 Tahun V (2010).

Quthb, Sayyid. Tafsir Fi Zhilalil-Qur'an: Di Bawah Naungan Al-Qur'an. Jakarta: Gema Insani Press, 2004.

Santrock, J. W. Psikologi Pendidikan. Jakarta: Kencana, 2010.

Shihab, M. Quraish. Tafsir AlMisbah; Pesan, Kesan Dan Keserasian Al Quran. Jakarta: Lentera Hati, 2002. 